\title{
Obstacles to Self-actualization of College Students-The Case of Gazi Faculty of Education
}

\author{
Safiye Sarici Bulut \\ Department of Guidance and Psychological Counseling, Gazi University, Turkey
}

Copyright $\mathrm{C} 2018$ by authors, all rights reserved. Authors agree that this article remains permanently open access under the terms of the Creative Commons Attribution License 4.0 International License

\begin{abstract}
The purpose of this study is to determine the obstacles to self-actualization of the college students. A large qualitative data was collected. The study group consists of a total of 748 students with 599 female and 149 male students studying in Gazi Faculty of Education. The study group was determined through convenience sampling, which is one of the purposeful sampling methods Content analysis was used for the analysis of the data. Inter-coder reliability coefficient was calculated, experts were consulted and conformability strategy was used so as to ensure trustworthiness of the study. In consideration with the findings, the college students stated that the obstacles to self-actualization were personal obstacles which include neurotic tendencies, lack of confidence, time management problems, lack of motivation, procrastination, lack of self-expression and stress. Students stated negative impact of the other people, problems related to socialization, social rules, lack of social support and obstacles against females as social obstacles; inability of the education system in revealing the individual skills, time spent in the school, exams, homework and negative teacher attitudes as obstacles in regard to education; and negative parent attitudes as parental obstacles. While small portion of the students stated that they had no obstacles to self-actualization, majority of them stated that they had no sufficient economic support in self-actualization. When the findings are analyzed, it can be said that the college students have obstacles in regard to belonging, being loved, and overcoming unconditional acceptance culture. The acquired findings were interpreted in accordance with the humanistic approach and the Maslow's hierarchy of needs.
\end{abstract}

Keywords College Student, Self-actualization, Self-actualization Obstacles.

\section{Introduction}

Humanistic psychology went ahead of the deterministic attitude of the psychoanalytical and behavioristic approaches in explaining the human behavior. By this means, the conscious experiences created the movement known as the third power in psychology by adopting themes such as integrity of the human nature and the creative power of the individual $(1,2)$. Humanistic psychology was influenced by the existential philosophy and gestalt approach and interpreted the human in a different framework than the previous institutions. The approach, which emphasized that the human has the ability to shape his/her own life, put forth that the most important motive that determines the human behaviors was self-actualization (2). Maslow, Rogers and Horney consider humanistic theory as holistic, dispositional and factual (3).

According to Goldstein, actualizing the whole capacity is the fundamental motive of the people and the term "self-actualization" was first put forth by him (4). According to Jung, the most important purpose of life is the individual's self-actualization (2). Jung associated the self-archetype he valued the most with the self-actualization. Self-archetype balances the subconscious and provides stability to the personality. Jung likened the self-archetype to a motive towards self-actualization and he defines self-actualization as personality in harmony and maturity in all aspects (1).

Although self-actualization is also studied by Jung, Horney and Rogers, it is known as a concept that is identified with Maslow. The self-actualization concept of Maslow is studied not as a personality syndrome but as part of a broad-based motivation theory (5). Maslow emphasizes that everyone has a motive in regard to self-actualization and that the biological and psychological needs, which were stated beginning from the very bottom level, must be met so that the individuals can actualize themselves. This hierarchy is expressed with physiological needs, safety needs, belongingness and love needs, esteem needs and self-actualization. Physiological needs are directly related with survival. Physiological needs include needs for food, water, sex and sleep. These needs are highly important and must be met. After the physiological needs are met, the need for safety comes out as the 
dominant motive. These needs include needs for structure, order and security predictability. After the physical and security needs are met, the individuals are motivated (directed) by the belonging need. This need includes peers and friends, support of family, being a member to a group and sincere relationships. If the individual's physiological, security, belonging and love needs are met; the need for respect will be the dominant motive. This need consists of recognition and acceptance by other people, self-respect, sense of sufficiency and competence, and trust. When these needs are sufficiently met, the individuals will be motivated by the self-actualization. The self-actualization consists of the actualization of their potentials and abilities. In addition, Maslow states that meeting the fundamental needs is related with the desire for knowing and understanding, and it is used as a tool in solving problems and overcoming difficulties. The desire for knowing and understanding exists at all motivational levels and depends on the hierarchical positions of the individuals. Since the beginning of the humanity, another need that is believed to have existed is aesthetics. This need is instinctive and reveals itself during the self-actualization of the individuals (7, 2, and 6).

Rogers, who is the leading representative of the humanistic psychology, unlike the negative, selfish, illogical definition of the humans by psychoanalytical theory and the objective analysis and conditioning statuses of the humans by the behaviorist theory, emphasizes that the human nature is good and when the human is left to his own devices, he has the tendency for self-actualization (8). Human is in need of internal growth and development; and the self-actualization throughout this process is considered as part of the actualization of the organism. Self-actualization stands both for the biological and the psychological development. Humanistic psychology includes concepts that are not really emphasized by the previous institutions such as love, creativity, meaning and self-actualization. In this approach, the self-understanding of the individuals and their abilities to structure their lives in productive ways in accordance with their abilities are trusted. It is emphasized that the power of development within people provides their betterment and the clients are supported to assume responsibilities. In this approach, the aim of the therapist is to help the individuals in overcoming the problems they are facing now or will face in the future. The root of the problem is the obstacles that prevent the constructive progress and development of the individuals. These obstacles include respect towards the individual as one of the fundamental principles of the humanistic individual; and when empathy, transparency and valuing spread during the therapy period, the clients will be freed from these obstacles through integrating these principles into their lives. The individuals must overcome the obstacles they face for change and development purposes. In this way, the individuals will be able to structure their lives in a realistic way $(14,12,13,11,10,9)$. The most important purpose of life is self-actualization of the individuals (7).

Self-actualization involves individuals' expressing themselves correctly and being psychologically healthy (1). Rogers emphasized the features that come forth in these individuals as clarity, living life fully, acting on insight, feeling of freedom and creativity (2). Maslow (15) gathered these features under the titles such as objective sense of reality, accepting your own experiences as is, responsibility, natural behaviors, independence, need for autonomy and privacy, democratic character and being creative.

Although self-actualization is innate, the experiences and learning processes during the childhood period can either support or obstacle the individuals in their self-actualization. In the childhood period, which has a critical importance in the creation of ego, meeting the child's need of love by the mother will provide positive contribution in the personality development and self-actualization of the child. Rogers state that approaching the child with unconditional love by the mother will ensure that the child internalizes these attitudes and add them into their value system, and otherwise the child would feel valuable only under certain conditions. In case unconditional love is given, the child cannot fully express himself with the fear of rejection and cannot fully develop his ego $(1,13)$. Maslow emphasizes that the disharmony between the self and self-representation of the individual negatively impact the mental health (16). Maslow also stated that, unless the child's need of parental love, security and respect is not met, it would be difficult for the child to reach his target of self-actualization $(6,16)$. In this case, there can be an inconsistency between the internalized conditions of value and the experiences of the individual, and the conflicts between the tendency to actualize and the self-actualization can cause malfunction in individuals (17). The individuals must overcome the obstacles to self-actualization for the revelation of their potentials. Otherwise, individuals may face with certain psychological problems (18). Similarly, Rogers state that all the psychological problems are caused by the prevention of the individual's actualization tendency (19).

Looking at the relationship between the parent attitudes and the self-actualization of the individuals, it was seen that while in democratic families providing opportunities such as love and understanding for children to actualize themselves is high, the authoritative approach characterized by the rigid and inconsiderate approach prevents the self-actualization of the individuals (20). In another study that analyzes the relationship between the parent attitudes and self-actualization, while there is a negative significant relationship seen in terms of part of Maslow's self-actualization hierarchy, there is a positive significant relationship for individuals that grew up in a democratic family (21). When the self-actualization obstacles of the college students are analyzed, it was seen 
that the self-actualization obstacle levels of the 4th graders were lower than the 1st graders (22). Throughout the self-actualization process, it is seen that family and school are important variables (23).

When the self-actualization is considered in terms of gender, it was seen that there was a significant difference in favor of females $(24,22,25,26)$. The fact that the self-actualization scores are high in favor of females could be explained with the consideration of the gender factor in the Turkish society. Especially since the men are seen as the guarantee of the future in rural communities, their social values can also be higher than the women (27). When the concept of self-actualization is considered in terms of Turkish culture, there is a relationship between the need for security, respect, self-actualization and individualist-collectivist culture structure (28).

College students are considered, in terms of development, as young adults. This period is a transition from adolescence to adulthood (approximately between the ages of 18-25) and includes various experiences and discoveries $(29,30)$. Individuals need to achieve various developmental duties in each life cycle. In this cycle, individuals must solve the conflict between the proximity and isolation $(2,32,31)$. In addition, the individuals make progress in overcoming the problems and actualizing the gender roles (33). Freud states that the needs of the individuals were love and work. Maslow $(15,34)$ emphasizes that the need for loving and owning turns into success and respect when the needs of the adulthood are met. When this period is analyzed in the general sense, it is seen that the social development and individual success are important for the adults (3). These students in young adulthood fulfill their development duties during their university education and also present their potential during their self-actualization process. In addition to the education processes that would reveal the potentials of the students in the Turkish education system, there are also guidance and counseling activities that would contribute to their personal social developments. In the definition of guidance, "the process of systematic and professional help given to individuals so that they can recognize the opportunities around them and actualize the self by making correct decisions" (35), "self-actualization" as one of the important concepts of humanistic psychology école makes up a significant dimension to it (36).

When the studies in regard to self-actualization are reviwed, it was seen that this concept were found in the fields of medicine, education, economics and psychotherapy $(42,41,40,38,37)$. It was seen that there is a positive and significant relationship between self-actualization and entrepreneurship (43), lifelong learning has important contributions to the self-actualization of the individuals (44), there is a positive relationship between loving the occupation and self-actualization (45). It was seen that there is a relationship between the low ethical judgment scores and low self-actualization scores (46). In a study aimed for the department of psychological counseling and guidance, it was found that psychological counseling with a group and occupational consultancy were effective in increasing the self-actualization levels of the individuals $(47,48)$. In addition, it was stated that gaining characteristics in regard to self-actualization for the students would increase their adaptation levels and life satisfactions (49).

In terms of mental health, Rogers views the obstacles to self-actualization tendencies as one of the most important causes of the psychological problems (19). The individuals must overcome the obstacles to self-actualization so that their potentials can come out and can mature. In consideration with the fact that average person today uses only 10-15 percent of his potential (18), it is thought that putting forth in this study the obstacles to self-actualization of the college students would contribute to reveal their potentials by helping the students understand the development process better. Learning about the obstacles to the self-actualization of the students would help the structuring of the preventive educational activities for the prevention and elimination of the creation of these obstacles during the formal and informal education process. Thus, when education process supports the self-actualization process of the individuals, the individuals can learn and understand about themselves better and find opportunities to reveal their potential. Through this study, it is thought that determining the obstacles to self-actualization and elimination of these obstacles through interventionist studies would provide positive contribution to the developments of the individuals. However, conducting this study only at the Gazi Faculty of Education is a limitation of the study. Research question of this study is: "What are the obstacles to self-actualization of the college students?

\section{Method}

\subsection{Research Design}

The study aims to determine the obstacles to self-actualization of the college students and its design is phenomenological research, which is one of the qualitative research methods. In this study design, the focus is on the phenomena that are recognized but not known in detail (52, 53, 51, and 50). In this study, the obstacles to self-actualization were studied in detail and depth.

\subsection{Participant Characteristics}

The study group was determined through convenience sampling, which is one of the purposeful sampling methods. With this method, the situations, which are thought to possess rich data, are studied in detail and this method is useful in terms of exploring and explaining facts and events 
$(51,53)$. The study group consists of a total of 748 students with 599 female and 149 male students studying in Gazi Faculty of Education. All of the participations volunteered for this study.

Table 1. Demographic information of study group

\begin{tabular}{|c|c|c|c|}
\hline \multirow{2}{*}{$\begin{array}{l}\text { University department } \\
\text { of the students }\end{array}$} & \multicolumn{2}{|c|}{ Gender } & \multirow[t]{2}{*}{ Total } \\
\hline & Female & Male & \\
\hline $\begin{array}{c}\text { Elementary school } \\
\text { mathematics teaching }\end{array}$ & 60 & 10 & 70 \\
\hline Science teaching & 78 & 7 & 85 \\
\hline Pre-school teaching & 53 & 9 & 62 \\
\hline Music teaching & 26 & 6 & 32 \\
\hline $\begin{array}{c}\text { Middle school } \\
\text { mathematics teaching }\end{array}$ & 11 & 2 & 13 \\
\hline Biology teaching & 11 & - & 11 \\
\hline Art teaching & 34 & 6 & 40 \\
\hline History teaching & 9 & 9 & 18 \\
\hline Classroom teaching & 93 & 23 & 116 \\
\hline $\begin{array}{l}\text { Psychological } \\
\text { counseling and } \\
\text { guidance }\end{array}$ & 94 & 20 & 114 \\
\hline $\begin{array}{c}\text { Computers and } \\
\text { instructional } \\
\text { technologies teaching }\end{array}$ & 17 & 13 & 30 \\
\hline $\begin{array}{c}\text { Turkish language } \\
\text { teaching }\end{array}$ & 40 & 8 & 48 \\
\hline $\begin{array}{c}\text { English language } \\
\text { teaching }\end{array}$ & 17 & 4 & 21 \\
\hline $\begin{array}{l}\text { Teaching of the visually } \\
\text { impaired }\end{array}$ & 27 & 5 & 32 \\
\hline Social sciences teaching & 29 & 27 & 56 \\
\hline Total & 599 & 149 & 748 \\
\hline
\end{tabular}

\subsection{Data Collection and Analysis}

In this study, the data was gathered with the questionnaire method in the education period of 2017-2018. In the questionnaire preparation process, the literature review was the primary source. In the questionnaire, genders of the students, information about their university departments were asked; meanwhile, the data, related to the obstacles about students' self-improvement were gathered with open-ended questions, such as "What are the obstacles to your self-actualization". The researcher made the necessary explanations for Maslow's hierarchy. The explanation included the concept of self- actualization, its importance in the process of education. The purpose of making the explanation process of the questionnaire was to allow the students to deeply express the obstacles to their self- actualization by clearly comprehending the concept of self- actualization. In this process, the questions of the participants were answered and the application was made in an interactive manner.

In the analysis of the data, the content analysis technique, including the processes of determining, coding and categorizing the patterns, based on the gathered data, was used. The analysis of the data was made by data cleaning, coding, data entry, grouping and creating themes. In the results section, frequencies and direct quotations from the data were reported. Since each participant expressed more than one opinion, the number of participants and the number of opinions differ.

After the data was entered, the theme extraction of process was done by two different coders. The percentage of consistency between the coders was calculated so as to provide the trustworthiness of the study. Afterward, in order to examine the confidence between coders, the percentage of consistency for every main theme was calculated as Agreement/(Disagreement Agreement) x 100 (54) as displayed in Table 2.

Table 2. Consistency rates

\begin{tabular}{ccccc}
\hline $\begin{array}{c}\text { Main } \\
\text { themes }\end{array}$ & $\begin{array}{c}\text { Number of } \\
\text { consistent } \\
\text { codes }\end{array}$ & $\begin{array}{c}\text { Number of } \\
\text { inconsistent } \\
\text { codes }\end{array}$ & Total & $\begin{array}{c}\text { Percentage } \\
\text { of } \\
\text { consistence }\end{array}$ \\
\hline $\begin{array}{c}\text { Personal } \\
\text { obstacles }\end{array}$ & 468 & 134 & 602 & $78 \%$ \\
\hline $\begin{array}{c}\text { Social } \\
\text { obstacles }\end{array}$ & 310 & 46 & 356 & $87 \%$ \\
\hline $\begin{array}{c}\text { Education } \\
\text { related } \\
\text { obstacles }\end{array}$ & 236 & 37 & 273 & $86 \%$ \\
\hline $\begin{array}{c}\text { Economic } \\
\text { obstacles }\end{array}$ & 228 & 5 & 233 & $98 \%$ \\
\hline $\begin{array}{c}\text { Parental } \\
\text { obstacles }\end{array}$ & 166 & 33 & 199 & $83 \%$ \\
\hline Total & 1408 & 255 & 1663 & $86.4 \%$ \\
\hline
\end{tabular}

The consistence between coders for each theme was calculated as $78 \%, 87 \%, 86 \%, 98 \%$ and $83 \%$. The general percentage of consistency was calculated as $86.4 \%$. The percentages of consistency based on themes show that the study has evidence for trustworthiness. In addition, direct quotations are given place in the study. Besides, the study process is depicted in detail.

\section{Results}

In this part, the findings about the obstacles to selfactualization of college students are displayed in Table 3. 
Table 3. Distribution of the self- actualization obstacles before the college students

\begin{tabular}{|c|c|c|c|c|}
\hline Obstacle type & & Female & Male & Total \\
\hline \multirow{10}{*}{ Personal obstacles } & $\begin{array}{l}\text { Neurotic tendencies (perfectionist thinking, pessimism, anxiety, suspicion, } \\
\text { stereotypes, unable to concentrate, feeling insecure, unable to cope with } \\
\text { problems, disliking his/her physical appearance) }\end{array}$ & 145 & 27 & 172 \\
\hline & Lack of self-confidence & 131 & 18 & 149 \\
\hline & Time management problems & 59 & 14 & 73 \\
\hline & Lack of motivation & 27 & 11 & 38 \\
\hline & Procrastination & 27 & 11 & 38 \\
\hline & Unable to express himself/herself & 26 & 4 & 30 \\
\hline & Stress & 23 & 1 & 24 \\
\hline & Learned helplessness & 18 & 3 & 21 \\
\hline & Not knowing himself/herself, unable to use his/her potential & 13 & 3 & 16 \\
\hline & $\begin{array}{l}\text { Others (Numerousness of responsibilities, health problems, technology } \\
\text { addiction) }\end{array}$ & 31 & 10 & 41 \\
\hline \multicolumn{2}{|l|}{ Total } & 500 & 102 & 602 \\
\hline \multirow{5}{*}{$\begin{array}{l}\text { Social obstacles (exposure } \\
\text { to environmental } \\
\text { conditions) }\end{array}$} & Negative impact of other people (What would they say?) & 157 & 28 & 185 \\
\hline & Problems related to socialization & 45 & 11 & 56 \\
\hline & Social rules & 44 & 11 & 55 \\
\hline & Lack of social support & 23 & 5 & 28 \\
\hline & Others (Gender related restrictions, communication problems, customs) & 28 & 4 & 32 \\
\hline \multicolumn{2}{|l|}{ Total } & 297 & 59 & 356 \\
\hline \multirow{8}{*}{ Education related obstacles } & Education's not revealing personal skills & 54 & 15 & 69 \\
\hline & Time spent at school & 37 & 5 & 42 \\
\hline & Examinations and assignments & 36 & 5 & 41 \\
\hline & $\begin{array}{l}\text { Mistaken attitudes of teachers (Teacher's behavior management, } \\
\text { insufficiencies related to academy and classroom management) }\end{array}$ & 31 & 7 & 38 \\
\hline & Concern about being unemployed at the end of the graduation & 17 & 7 & 24 \\
\hline & $\begin{array}{l}\text { Problems related to education department (contents of courses, teaching } \\
\text { methods) }\end{array}$ & 13 & 9 & 22 \\
\hline & Not providing necessary guidance in the academic processes & 15 & 7 & 22 \\
\hline & Studying at a department which is not suitable with his/her skills & 13 & 2 & 15 \\
\hline \multicolumn{2}{|r|}{ 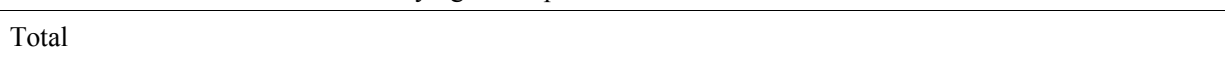 } & 216 & 57 & 273 \\
\hline Economic obstacles & $\begin{array}{l}\text { Lack of necessary economic support for the activities that are to be made for } \\
\text { self-improvement }\end{array}$ & 175 & 58 & 233 \\
\hline Parental obstacles & $\begin{array}{l}\text { Negative parental attitudes (authoritarian attitude, high expectations from the } \\
\text { child, not accepting the child as he/she is, restrictive attitudes, not supporting } \\
\text { the skill and the child, domestic problems) }\end{array}$ & 172 & 27 & 199 \\
\hline \multicolumn{2}{|c|}{ Those who do not have any obstacles toward developing themselves } & 12 & 2 & 14 \\
\hline \multicolumn{2}{|r|}{ Total } & 1372 & 305 & 1677 \\
\hline
\end{tabular}

When the obstacles to self-actualization of the college students to realize themselves are taken into consideration, it is seen that personal obstacles $(\mathrm{f}=602)$ are neurotic tendencies $(\mathrm{f}=172)$, lack of self-confidence $(\mathrm{f}=149)$, time-management problems ( $\mathrm{f}=73$ ), lack of motivation $(\mathrm{f}=38)$. After the personal obstacles, the social obstacles $(\mathrm{f}=356)$ are the negative impact of other people $(\mathrm{f}=185)$, problems about socialization $(\mathrm{f}=56)$, social rules $(\mathrm{f}=55)$ and lack of social support $(\mathrm{f}=28)$. The students stated the obstacles about the education system $(\mathrm{f}=273)$ are inability of educational system to reveal personal skills ( $\mathrm{f}=69$ ), too much time spent at school ( $\mathrm{f}=42)$, examinations and assignments ( $\mathrm{f}=41)$, mistaken attitudes of teachers $(\mathrm{f}=38)$. It is seen that an important number of students $(\mathrm{f}=233)$ pointed out the economic obstacles in their self-actualization. It is seen that the students have obstacles, including the parental obstacles, such as the negative parental attitudes, in their self-actualization $(\mathrm{f}=199)$ and that a small number of the students state that they do not have any obstacle to their self- actualization $(\mathrm{f}=14)$.

The examples for the most repeated themes by the college students are presented below. 
"I am not enthusiastic about revealing my potentials" (Female, Mathematics Teaching Department)

"The negative comments of other people about myself prevent me from revealing my potentials" (Female, Turkish Language Teaching Department)

"The examination system in our country drags me away from revealing my potential" (Female, Turkish Language Teaching Department)

"I spent a lot of time on the Internet" (Male, Social Sciences Teaching)

"It prevents me that there are not people that understand and support me" (Female, Social Sciences Teaching Department)

"When I want to gain hobbies like playing a musical instrument, dancing or photography, my family prevents and does not support me" (Female, Teaching of the Visually Impaired)

"I do not have self-confidence" (Male, English Teaching Department)

"I really want to go to a piano course, but my economic condition does not allow for that" (Female, Mathematics Teaching)

"The role and behaviors that are expected by society from women prevent me" (Female, Biology Teaching)

"The lack of self-confidence and the thought that I will fail however I study really hard" (Male, Pre-school Teaching)

"That I get upset due to even the smallest things, feel anxiety and overthink everything" (Female, Pre-school Teaching)

"I am a perfectionist; I do not feel comfortable when I do not complete everything" (Female, Music Teaching)

\section{Discussion and Conclusion}

The answers of the college students were analyzed and the themes of personal, social, educational system related, economic and parental obstacles were observed. It is seen that the obstacles to self-actualization varied in the categories that the students frequently repeated.

In terms of personal obstacles, the neurotic tendencies and lack of self-confidence in the students draw attention. The parental attitudes and whether the fundamental needs of the child such as love, confidence and respect were met play the decisive role in the creation of the obstacles. When the obstacles that were stated by the students in the study group are taken into consideration, it is seen that parents cannot support their children enough. What lie under psychological problems is parental expectations (18). This expression is made by the students as "Having high expectations." The neurotic tendencies that the students expressed like perfectionist thinking, pessimism, anxiety, suspicion, stereotypes, being unable to concentrate, feeling insecure and being unable to cope with problems $(55,56)$ remark the inconsistencies between their values and life experiences, alongside with the conflicts between their self-actualization tendencies and actual self- actualization. These conflicts may cause dysfunctions in individuals (17). Also, it is seen that there is a relation between perfectionism and the low scores of self- actualization, and the low self- actualization scores are the signs of disorders (57). Not meeting the needs of the students like belonging and being loved can cause the senses of loneliness and hopelessness in them $(1,13)$. The negative attitudes of individuals are accepted, but these are the results of the environmental interaction and not caused by themselves $(12,2,11,10,9)$. Rogers states that all psychological problems are a cause of preventing the tendencies of an individual to actualize him (19).

The college students stated time-management problems, lack of motivation, procrastination, being unable to self-express, learned helplessness, not knowing him/her, numerousness of responsibilities, health problems and technology addiction as the obstacles to self- actualization. The negative impact of other people (What would other people say?) can be framed as the problems about socialization, social rules, lack of social support, restrictions that the gender of women cause, communication problems and traditional social obstacles. It is seen that the interactions of the individuals with the social environment, in which they lived, have negative impact on their self- actualization (58). It can be said that the students are in a period of self- actualization; nonetheless, they have problems in terms of unconditional acceptance and overcoming culture.

Students also remarked that they had obstacles about the education system. These were gathered under the main titles of education's not revealing skills, time spent at school, examinations and assignments, their insufficiencies related to academy and classroom management, problems about being unemployed after graduation, problems about the study field, not providing necessary guidance in the academic processes and studying at a department which is not suitable with his/her skills. The insufficiency of the sense of belonging, being respected and accepted in the educational environments plays a preventive role in students' developing themselves (11). When the obstacles, caused by the educational processes, are taken into consideration, it is seen that the application of humanistic education programs in today's schools is an important necessity (59). When humanistic approaches are applied enough and when the acquisitions like respect and critical-thinking are provided, it can be said that the obstacles that are caused by schools in terms of will be overcome in terms of self- actualization (60). Besides, the fact that an important number of students emphasized the economic obstacles underlines that their security needs are 
not met completely and there is a relationship between their attitudes to money and self- actualization (61).

The college students stated the authoritarian attitude, high expectations from parents, not accepting the child as how he/she is, restrictive attitudes, not supporting the skill and child and domestic problems as parental obstacles. The parental attitudes play an important role in the process of self-actualization. That the parents meet the fundamental needs of the children, such as love, security and acceptance will allow them to avoid emotional chaos and support them to realize themselves. Maslow emphasizes that if the parents do not meet the stated needs of the children, it will be difficult for them to achieve their goals $(6,16)$. The studies that examine the relationship between the attitudes of parents and self-actualization point out that the individuals who grew up in democratic families had high levels of self-actualization, whereas the authoritative parental attitudes prevent them. Moreover, in terms of respect that is given place in Maslow's hierarchy of needs, while a negative relationship is observed in the individuals who grew up in authoritarian families, a positive relationship is observed in the individuals who grew up in democratic families (21-20).

The students intensely expressed the environment and environmental obstacles that are caused by the personal, social, education system-related and parental obstacles, in self-actualization. As it is also wanted to be emphasized in the humanistic theory, the reason of pathology in humans is caused by negative environmental conditions. It can be said that, in case of such preventions, students may have problems on reaching a meaningful life (62). When the obstacles of the college students in self-actualization are examined, it is seen that the students are in the process of self-actualization, although they have obstacles at different levels. It is because self-actualization can be distorted but cannot be destroyed (8).

As the results of this study pointed out, the obstacles to self-actualization of the college students could be addressed under five sub-themes. The obstacles that were stressed the most frequent by the college students were related to personal matters such as neurotic trends, lack of self-confidence, time management problems, lack of motivation, procrastination, lack of self-expression, and stress. The second group of obstacle themes that were stressed by the participants were related social obstacles, social rules, and lack of social support. The third group of themes was related to educational system. Those obstacles were due to length of time spent at school, exams, homework assignments, and improper treatment of teachers towards students. Lastly, financial conditions, parental matters could be counted as the least frequently reported obstacles to self-actualization.

\section{Suggestions}

a When the obstacles before the college students in self-actualization were examined, it was seen that the most repeated content was related to the personal space. As increasing their self-actualization skills will make them healthier, various trainings and individual and group solidarity processes can be benefited from in this direction. Therefore, the skills of the individuals can be developed in terms of overcoming their education-related and parental obstacles.

b An important part of the obstacles before the college students' self-actualization is also consisted of the obstacles, related to the education system. In this matter, it can be recommended that their behaviors toward realizing themselves can be reinforced, supported and encouraged. Structuring the variables in the school system in manner that it can allow students to realize themselves can support especially teachers to benefit from the necessary in-service trainings about mistaken teacher attitudes and students to realize themselves. As providing that the school system allows students to express themselves freely, to be respected and understood will allow the individuals positively in their self-actualization processes, it can be recommended to organize the education policies, programs and teachers' applications. It is predicted that the personal and academic development will be provided in the students that will find an opportunity to reveal their potentials and the negative behaviors will decrease.

c Making the students acquire the traits about self-actualization will increase their adaptation and life satisfaction levels; by this reason, the events like "self-actualization activities" should be included in the education programs. It is thought that the self-actualization activities will allow students to get rid of the obstacles before their self-actualization and have a positive role in reducing their anxiety.

\section{REFERENCES}

[1] Schultz, D. P. \& Schultz, S. E. Modern psikoloji tarihi. İstanbul: Kaknüs; 2007.

[2] Hergenhahn, B. R., \& Olson, M. H. In Introduction to theories of personality. Sixth edition. USA: Prentice Hall; 2003.

[3] Gerring, R. J., \& Zimbardo, P. G. Psikolojiye giriş, 19. Basım. Ankara: Nobel; 2012.

[4] Goldstein, K. The organism. New York, NY: American Books; 1939.

[5] Daniels, M. The development of the concept of self-actualization in the writings of Abraham Maslow. Current Psychological Reviews, 1982, 2: 61-76.

[6] Maslow, A. H. The Journals of A. H. Maslow, (Ed. Richard 
J. Lowry). California: Brooks/Cole Publishing Company; 1979.

[7] Krems, J. A., Kenrick, D. T. \& Neel, R. Individual perceptions of self-actualization: What functional motives are linked to fulfillin one's full potential? Personality and Social Psychology Bulletin, 2017, 43(9): 1337-1352.

[8] Rogers, C. R. The foundations of the person-centered approach. In A way of being (pp. 113-136). Boston: Houghton Mifflin. ; 1980.

[9] Rogers, C. R. Client-centered therapy. Boston: Houghton Mifflin; 1951.

[10] Rogers, C. R. A theory of therapy, personality, and interpersonal relationships: as developed in the client-centered framework. New York: McGraw Hill; 1959.

[11] Rogers, C. R. On becoming a person, Boston: Houghton Mifflin Company; 1961.

[12] Corey, G. Psikolojik danışma, psikoterapi kuram ve uygulamalar1. Ankara: Mentis; 2005.

[13] Dolliver, R. H. Carl Rogers's personality theory and psychotherapy as a reflection of his life experience and personality. Journal of Humanistic Psychology, 1995, 35(4): 111-128.

[14] Morgan, J. H. On becoming a person (1961) Carl Rogers' celebrated classic in memoriam. Journal of Psychological Issues in Organizational Culture, 2011, 2(3): 95-105.

[15] Maslow, A. H. Motivation and personality. New York: Harper \& Row; 1970.

[16] Maslow, A. H. Motivation and Personality. New York: Harper and Row Pub; 1954.

[17] Murdock, N. L. Psikolojik danışma ve psikoterapi kuramları, olgu sunum yaklaşımıyla, (Çev. Ed. Füsun Akkoyun), (İkinci Basım). Ankara: Nobel; 2012.

[18] Perls, F. Hefferline, R. F. \& Goodman, P. Gestalt therapy: Excitement and growth in the human personality, New York: Gestalt Journal Press; 1951.

[19] Nelson-Jones, R. The Teory and practice of counseling psychology. Cassell Educational Limited; 1982.

[20] Kuzgun Y. Ana-baba tutumlarının bireyin kendini gerçekleştirme düzeyine etkisi. Hacettepe Sosyal ve Beşeri Bilimler Dergisi, 1973, 5(1): 57-70.

[21] Dağlı, G., \& Beyazsaçl1, M. Evaluation of the correlation between parental behavior and levels of self-actualization. Mediterranean Journal of Educational Research, 2010, 7: 17-29.

[22] Ertem, F. \& Sezer, Ö. Üniversite 1. ve 4. Sinıf öğrencilerinin kendini gerçekleştirme engel düzeylerinin bazı değişkenlere göre incelenmesi. XIII Ulusal Eğitim Bilimleri Kurultay1, 6-9 Temmuz, 2004, İnönü Üniversitesi, Eğitim Fakültesi, Malatya.1-14.

[23] İmamoğlu, S. E. An investigation of teacher candidates' personal orientations with regard to self-actualization. e-Journal of New World Sciences Academy, NWSA-Education Sciences, 2012, 1C0572, 8, (1): 63-78.

[24] Hogan, H. W \& McWilliams, J. M. Factors related to self-actualization. The Journal of Psychology, 2010, 100(1): 117-122.

[25] Ekebaş, M. Lise son sınıf öğrencilerinin kendini açma davranışlarını etkileyen bazı etmenler (Yayınlanmamış doktora tezi). Ankara: Hacettepe Üniversitesi; 1994.

[26] Akbaş, A. Ergenlerin kendini gerçekleştirme düzeylerini etkileyen bazı faktörler, Doktora tezi, Ankara: Hacettepe Üniversitesi Sosyal Bilimler Enstitüsü; 1989.

[27] Kağıtçıbaşı, Ç. İnsan ve insanlar, Üçüncü Baskı, İstanbul: Cem Ofset Basımevi; 1979.

[28] Demir, H. \& Okan, T. Motivasyon üzerinde ulusal kültür etkisi. Gazi Üniversitesi İktisadi ve İdari Bilimler Fakültesi Dergisi, 2009, 11(1): 121-142.

[29] Santrock, J. W. Yaşam boyu gelişim, (Çev. Ed. Galip Yüksel). Ankara: Nobel; 2011.

[30] Kılıççı, Y. Okulda ruh sağlığı. Ankara: Anı; 2006.

[31] Erikson, E.H. Identity and life cycle. New York: W. W. Norton \& Company,Inc; 1980.

[32] Miller, P. H. Theories of developmental psychology. New York: Worth Publishing; 2002.

[33] Onur, B. Gelişim Psikolojisi, Yetişkinlik, Yaşlılık, Ölüm. Ankara: İmge; 2008.

[34] Maslow, A. H. Toward a psychology of being (2nd ed). Princeton, NJ: Van Nostrand; 1968.

[35] Kuzgun, Y. Psikolojik danışma ve rehberlik. (Dokuzuncu bask1). Ankara: Nobel; 2008.

[36] Yeşilyaprak, B. 21. Yüzyılda eğitimde rehberlik hizmetleri. 21. Basım, Ankara: Nobel; 2012.

[37] Brooker, G. An Instrument to Measure Consumer Self-Actualization, in NA - Advances in Consumer Research, Volume 02, eds. Mary Jane Schlinger, Ann Abor, MI: Association for Consumer Research, 1975: 563-576.

[38] Clair,C., Pickard, M. R. \& Harlow, K. Continuing education for self-actualization: Building a plan for rural nurses. The Journal of Continuing Education in Nursing, 1986, 17(1): 27-31.

[39] Lauring, J. Creating the tourist product in the opposition between self-actualization and collective consuption. Journal of Hospitality \& Tourism Research, 2011, 37(2): 217-236.

[40] Murtaza, N. Pursuing self-interest or self-actualization? From capitalism to a steady-state, wisdom economy. Ecological Economics, 2011, 70(4): 577-584.

[41] Sadri, G., Bowen, C. R. \& Clarke, R. Meeting employee requirements: Maslow's hierarchy of needs is still a reliable guide to motivating staff, Industrial Engineer, 2011: 44-48.

[42] Howell, R. T., Kurai, M. \& Tam, L. Money buys financial security and psychological need satisfaction: Testing need theory in affluence. Social Indicators Research, 2013, 110(1): 17-29.

[43] Heydari, H., Madani, D., \& Rostami, M. The study of the relationship between achievement motive, innovation, ambiguity tolerance, self-efficacy, self-esteem and self-actualization with the orientation of entrepreneurship in the Islamic Azad University of Khomein students. 
Procedia-Social and Behavioral Sciences, 2013, 84: 820-826.

[44] Akçay, C., \& Akyol, B. Self-actualization levels of participants in lifelong education centers. Procedia-Social and Behavioral Sciences, 2014, 116: 1577-1580.

[45] Ünsar, S., Akgün Kostak, M., Kurt, S. \& Erol, Ö. Self-actualization levels of nurses and affecting factors. Dokuz Eylül Üniversitesi Hemşirelik Yüksekokul Elektronik Dergisi, 2011, 4(1): 2-6.

[46] Karakavak Çırak, G. Üniversite öğrencilerinin ahlaki yarg1 yetenekleri ve ahlaki yargı yetenekleri ile kendini gerçekleştirme düzeylerinin karşılaştırılması, (Yayınlanmamış yüksek lisans tezi). Adana: Çukurova Üniversitesi Sosyal Bilimler Enstitüsü; 2006.

[47] Barnette, E. L. Effects of a growth group on counseling students' self-actualization. The Journal for Specialists in Group Work, 2008, 14: 202-210.

[48] Sackett, S. J. Career counseling as an aid to self-actualization, Journal of Career Development, 1998, 24(3): 235-242.

[49] Akbaba, S. Psikolojik sağlığ1 koruyucu rehberlik ve psikolojik danışma. Ankara: Pegem; 2004.

[50] Bogdan, R. C., \& Biklen, S. K. Qualitative research for education: An introduction to theory and methods (2nd ed.). Needham Heights, MA: Allyn and Bacon; 1992.

[51] Patton, M. Q. Qualitative research and evaluation methods (3rd Edition). Thousand Oaks, CA: Sage; 2002.
[52] Büyüköztürk, S., Kılıç Çakmak, E., Akgün, O. E., Karadeniz, S., \& Demirel, F. Bilimsel araştırma yöntemleri. Ankara: Pegem; 2017.

[53] Yıldırım, A., \& Șimșek, H. Sosyal bilimlerde nitel araștırma yöntemleri. Ankara: Seçkin; 2016.

[54] Miles, M. B \& Huberman, A. M. Qualitative data analysis: An expanded sourcebook. (Second Edition). California: SAGE; 1994.

[55] Costa, P. T., \& McCrae, R. R. Revised NEO Personality Inventory. Psychological Assessment Resources, 2000, 2-18.

[56] Işık, E. Nevrozlar, Ankara: Baskı Kent Matbaa; 1996.

[57] Flett, G. L., Hewitt, P. L., Blankstein, K. R., \& Mosher, S. W. Perfectionism, self-actualization, and personal adjustment. Journal of Social Behavior and Personality, 1991, 6(5): 147-160.

[58] Daniels, M. The Myth of self-actualization. Journal of Humanistic Psychology, 1988, 28(1): 7-38.

[59] Farmer, R. Hümanistic education and self-actualization theory, Education, 1984, 105(2): 162-72.

[60] Bledsoe, G. M. Self-actualization: The purpose of education. NASSP Bulletin, 1975, 59(592): 88-93.

[61] Oleson, M. Exploring the relationship between money attitudes and Maslow's hierarchy of needs, International Journal of Consumer Studies, 2003, 28(1): 83-92.

[62] Yazgan İnanç, B., \& Yerlikaya, E. E. Kişilik Kuramları, Ankara: Pegem; 2017. 